\title{
National and Organizational Culture, Performance Evaluation and Trust: Evidence from Multinational Company Subsidiary in Indonesia
}

\author{
Unggul Purwohedi \\ Universitas Negeri Jakarta \\ upurwohedi@unj.ac.id
}

\begin{abstract}
The aim of this study is to investigate the impact of national and organizational culture on the relationship between accounting and trust in a subsidiary of a Western Multi-National Company (MNC) in Indonesia. This study use a qualitative field study of one French MNC subsidiary and interview four expatriate directors, nine Indonesian managers and 10 Indonesian employees. Key themes were identified with the assistance of NVivo software. In this study, accounting, through formal performance evaluation, contributes to trust building between supervisors and their subordinates. Formal performance evaluation through transparent and objective evaluation increases trust in the supervisor. On the other hand, informal performance evaluation tends to decrease trustful behaviour due to secrecy in the evaluation process. It appears that Indonesian national culture does influence organizational culture preference in the local staff. Individuals share national culture as a result of values developed from family, religion, education, and experience.
\end{abstract}

Keywords: national culture, organizational culture, performance evaluation, trust

\begin{abstract}
Abstrak
Tujuan dari penelitian ini adalah untuk mengetahui dampak budaya nasional dan organisasi terhadap hubungan antara akuntansi dan kepercayaan pada anak perusahaan multi-nasional (MNC) di Indonesia. Penelitian ini menggunakan studi lapangan kualitatif dari satu anak perusahaan MNC Prancis dan mewawancarai empat direktur ekspatriat, sembilan manajer Indonesia dan 10 karyawan Indonesia. Tema kunci diidentifikasi dengan bantuan perangkat lunak NVivo. Dalam studi ini, akuntansi, melalui evaluasi kinerja formal, berkontribusi pada pembangunan kepercayaan antara supervisor dan bawahan mereka. Evaluasi kinerja formal melalui evaluasi yang transparan dan obyektif meningkatkan kepercayaan pada atasan. Di sisi lain, evaluasi kinerja informal cenderung mengurangi perilaku amanah karena kerahasiaan dalam proses evaluasi. Tampak bahwa budaya nasional Indonesia memang mempengaruhi preferensi budaya organisasi di staf lokal. Individu berbagi budaya nasional sebagai hasil nilai yang dikembangkan dari keluarga, agama, pendidikan, dan pengalaman.
\end{abstract}

Kata Kunci: budaya nasional, budaya organisasi, evaluasi kinerja, kepercayaan

Received: January 27, 2017; Revised: May 21, 2017; Approved: June 10, 2017 
National and Organizational Culture...

Unggul Purwohedi

\section{INTRODUCTION}

Multinational companies have attracted much scholarship from different perspectives (Buckley and Casson, 2009; Leung, et.al, 2005; Levy, et.al, 2007). Many literature for the last two decades has discussed this issue, to better understand how a multinational company operates in many different countries (Chow, et.al, 2002; Chow, et.al, 1996; Chow, et.al, 1999; Dossi and Patelli, 2008). In more recent years, there is an increasing interest in how multinational companies deal with one important factor in interpersonal relationships, that is, trust (Busco, et.al, 2008; Busco, et.al, 2006; Moilannen, 2008; Vosselman and Meer-Kooistra, 2009). Trust is a primary evidence of the international partnership process between any MNC headquarters (HQ) and their subsidiaries. Moreover, current research argues that in the process of trust building within MNCs worldwide, accounting plays an important role. Accordingly, we try to discover the interplay between accounting and trust in the multinational company from Giddens' (199I) perspectives which has appeared in recent literature (Busco, et.al., 2006; Moilannen, 2008).

Giddens (199I) argued that one of the challenges to organizations is disembedding of social systems.. In the context of MNCs, it can be inferred that accounting as an expert system enables MNCs to organize and control their operations through a single common language across countries. On the other hand, accounting may not serve as a common language in MNCs if business and social structures and their people have different understandings of accounting concepts (Evans, 2004). Difficulties can emerge due to the local context in which subsidiaries operate (Moilannen, 2008), local resistance towards controls imposed by the parent company (Siti-Nabiha and Scapens, 2005), and the resilience of an existing accounting system developed locally by the subsidiary (Dossi and Patelli, 2008).

Moilannen (2008) shows how different social systems of the business units become linked in a management control in Western MNC subsidiaries across some former Soviet Union countries. By employing Giddens' notion, he argues that: 
The current theoretical framework reveals how different organizational (and national) cultures interact in the hierarchical organization structure and how power can be used in different parts of the organization to justify actions. The discussion above shows that a Western firm easily regards a subsidiary in a transitional economy with some suspicion and might thus treat subsidiaries differently (Moilannen, 2008: 265).

Moilannen's statement indicates a possible future direction of accounting research in investigating the role of cultures, in a local context, on accounting. A lot of research seeks to understand how culture could contribute to accounting (e.g. Bhimani, 1999; Chow et al., 2002; Harrison and Mckinnon, 1998; O'Donnell and Prather-Kinsey, 2010). Relationships between culture and accounting move beyond their original discourse by acknowledging trust as the outcome of the process (Moilanen, 2008). So far, however, there has been little attention to the impact of culture, as manifested in local contexts, on the accounting and trust relationship. We aim to address this gap by investigating how culture affects accounting practices (henceforth, we mean specifically the performance evaluation formality) and in turn, the implication of performance evaluation on trusts building in one MNC subsidiary, in one emerging economy, Indonesia.

This section commences with an explanation of Giddens' (1991) concepts of embedding and re-embedding which helps explain the role of accounting and its connection with trust, particularly in the MNC context. Moreover, through this discussion, this section will highlight the importance of national and organizational culture as a manifestation of local systems in the literature. The concept of national and organizational culture will be elaborated in this section.

Organizations can separate time and space, and form standardized dimensions which cut through the connections between social activity and its "embedding" in present contexts. Giddens argued that disembedded institutions greatly extend the scope of time-space distanciation and, to have this effect, depend on coordination across time and space. Giddens defines the disembedding of social systems as "lifting out" of social relations from local contexts of interaction and their restructuring across indefinite spans of time-space (Giddens, 1991). There are two types of disembedded mechanisms: symbolic tokens and expert systems. Symbolic token is a media of interchange, which can be "passed around" without regard to the specific characteristics of individuals or groups that handle them at any particular juncture. 
National and Organizational Culture...

Unggul Purwohedi

Expert systems are disembedding because they remove social relations from the immediacies of context. Accounting is a special disembedding mechanism because it is an expert system which uses money as a symbolic token, that is represents other forms of data in terms of money (Jones and Dugdale, 200I). Accountants could manipulate time, for example, when discounting cash flows, but they also create spaces around accounting entities that might not have any physical counterparts (Carmona, et.al, 2002). People live under an accounting regime, where accounting operates more broadly than it appears on the surface of specific practices, as it is embedded in, and constitutes, social relations (Jones and Dugdale, 200I).

Specifically, in the context of MNC, a subsidiary may use accounting differently in discursive practices. In a conventional MNC, where the parent explicitly controls its subsidiaries through (accounting) results, the parent has command over the allocated resources. In fact, the command over authoritative resources may be largely left to subsidiaries, which can organize the compilation of accounting information for required reports (Moilnannen, 2008). Therefore, MNC's Headquarter needs to take account of local knowledge influence regarding accounting procedures which are then utilised by headquarter through the reembedding process. Giddens defines reembedding as "the reappropriation or recasting of disembedded social relations so as to pin them down to local conditions of time and place" (Giddens, 199I). In order to pin down the embedded mechanism (symbolic tokens and expert system), the reembedding process requires trust. Giddens provides two types of trust: trust in systems and trust in person. Thus, in accounting as an example of the reembedding process, the importance is not only in the correctness of accounting principles being used (trust-in-systems), but also the local individuals applying those principles (trust-in-persons).

Several studies have revealed the connection between accounting and trust. Vosselman and Meer-Kooistra (2009) distinguished between accounting for control and accounting for trust. In accounting for control, accounting helps to create incentives, safeguard or constrain the actors of parties involved. In the trust context, accounting serves the process of relational signalling, a process that they argue to be at the heart of the trust-building process. Accounting helps to stimulate people's willingness to accept vulnerability. For example, in reference to inter-firm transactional relationships, accounting for control arrives in the form of a formal control device and 
helps align the interests of parties involved. In so doing, accounting produces 'thin' trust. Thin means it only rests on compensation for negative behavioural expectations without by itself producing positive behavioural expectations.

Moreover, Vosselman and Meer-Kooistra (2009) argued that there is an additional need for the building of 'thick' trust through positive behavioural expectations about the behaviour of other parties. Thick trust complements thin trust with positive expectations about the ability, benevolence, and integrity of the other party. Trust is built gradually by monitoring the relational signal for each party. Accounting can help in this process by increasing one party's perception that another party has similar goals and values. Accounting is a mechanism that facilitates reaching a situation of sharing rather than exchange.

Busco, et.al (2006) challenge accounting in response to change in an organization. Busco, et.al (2006) conducted their research in an Italian company (NuovoPignone) that had been acquired by Western MNC (General Electric/GE). The parent company introduced a new organizational culture to the subsidiary where new MAS became part of the change process. They discovered that MAS participated in the creation of trust for change, as it contributed to the perceived trustworthiness of the GE way of doing things and the new solutions it offered.

In particular, in the MNC context, Moilannen (2008) indicated that establishing a link between local systems and the required accounting system in a Western firm may become important. This is because the role of accounting has changed in the Western world in recent decades. Furthermore, he argued that organizational (and national) cultures interact in organization structure, and those cultures can change head office's approach to its subsidiaries in different countries. Therefore culture, in national and organizational terms, has emerged as part of the local system that MNCs should be aware of. In that sense, we will investigate the interaction between national and organizational culture and how it could impact on performance evaluation practices. In particularly, first we will investigate how national culture could contribute to organizational culture orientation within MNC subsidiary. Then, how this organizational culture orientation could affect the formality of performance evaluation. Lastly, this study will find out the impact of this 
National and Organizational Culture...

Unggul Purwohedi

performance evaluation preference on the interpersonal trust building between subordinates and their supervisors.

This study was conducted in Indonesia which has high scores in two culture dimensions: power distance and collectivism (Hofstede, 200I). Table I shows that Indonesia's index in those cultural dimensions could serve as the basis of differentiating Indonesia from other countries. Based on those scores, Indonesia is the country, which has the high rank in Power distance dimension and low rank in individualism, which denotes to collectivist country. According to Masculinity and uncertainty avoidance dimensions, Indonesia is among the lowest ranks in those dimensions. Thus, Indonesian power distance profile reflects the inequality in power relationships in organizations. This inequality is usually formalized in supervisor-subordinate relationships. On the other hand, the collectivist culture of Indonesian represents the emphasis on the community, shared values and social beliefs maintenance.

Table .I. Indonesia and other countries' cultural dimensions profile

\begin{tabular}{|c|c|c|c|c|c|c|c|c|}
\hline \multirow[t]{2}{*}{ Country } & \multicolumn{2}{|c|}{ Power Distance } & \multicolumn{2}{|c|}{ Individualism } & \multicolumn{2}{|c|}{ Masculinity } & \multicolumn{2}{|c|}{$\begin{array}{l}\text { Uncertainty } \\
\text { Avoidance }\end{array}$} \\
\hline & Index & Rank & Index & Rank & Index & Rank & Index & Rank \\
\hline Indonesia & 78 & $8-9$ & 14 & $\overline{47-48}$ & 46 & $30-31$ & 48 & $4 \mid-42$ \\
\hline Malaysia & 104 & I & 26 & 36 & 50 & $25-26$ & 36 & 46 \\
\hline Singapore & 74 & 13 & 20 & $39-41$ & 48 & 28 & 8 & 53 \\
\hline Australia & 36 & 41 & 90 & 2 & 61 & 16 & 51 & 37 \\
\hline UK & 35 & $42-44$ & 89 & 3 & 66 & $9-10$ & 35 & $47-78$ \\
\hline France & 68 & $15-16$ & 71 & $10-11$ & 43 & $35-36$ & 86 & $10-15$ \\
\hline Canada & 39 & 39 & 80 & $4-5$ & 52 & 24 & 48 & $4 \mid-42$ \\
\hline USA & 40 & 38 & 91 & I & 62 & 15 & 46 & 43 \\
\hline
\end{tabular}

Source: Hofstede (200I)

This study makes several contributions to the current understanding of MNCs. First, we go some way towards enhancing our understanding of how accounting affects on trust building in MNC subsidiaries, especially in Indonesia. Second, we provide evidence that performance evaluation can be transferred to different national culture backgrounds. Third, this study develops a previous discussion about the role of performance evaluation in the relationship between organizational culture and trust. Fourth, the results enable us to better understand the impact of national culture on MNC subsidiaries. 


\section{METHOD}

This research was a field study of a French MNC subsidiary in Indonesia under the pseudonym of Delta Indonesia. Delta supplies energy using different sources such as hydro-electricity and steam and now includes electricity transmission. Delta Indonesia is located in two cities in Indonesia, where Alpha is the sales office and Beta is the factory. The major client is Indonesia's state-owned electric company through some undergoing projects such as in building, maintaining and operating major power plants throughout Indonesia. Apart from that, Delta Indonesia also provides a special service to some private companies for their energy solutions.

During the past 17 years, three different companies from three different countries have owned Delta Indonesia. Those three countries' cultures appear to have shaped local members mindset and practices. Most of the managers have worked for a long period in the company, whilst other employees are mostly newcomers. Most of the permanent employees are engineers and most of the shop-floor level employees work on a contract basis. Project workers are employed on a project basis. Delta Indonesia has four Strategic Business Units (SBUs) in which each SBU has been led by one expatriate director from four different countries: Canada, USA, Germany, and France. One of the directors is also responsible as country president and coordinates all SBUs in Indonesia and represents the stakeholders in Indonesia. Thus, his role is different from a CEO who has the full authority and chain of command to the local organization. A country president is more a coordinator SBU's in Indonesia and as a spokesperson to Indonesian authority. Each director has a direct report supervisor in the regional offices in Malaysia, Switzerland and France.

Delta Indonesia has two different locations, Alpha and Beta offices; they needed to coordinate my study with their team in both offices. This study conduct interviews with three levels of organizational members ranging from director, manager, and employee. At the director level, my contact persons in Delta Indonesia agreed that all of the interviewees should be expatriates and in charge of an SBU of Delta Indonesia. For local Indonesian participants we sampled only permanent employees because they have a better understanding of their job and how the company operates. In total there are four expatriate directors, nine local managers and 10 local employees; all participants remained anonymous in this study. 
National and Organizational Culture...

Unggul Purwohedi

The interview instrument consists of 5 sections: personal information; national culture; organizational culture; performance evaluation formality; and interpersonal trust. The personal information section contains demographic questions such as job position, gender, nationality, age, educational background, number of years working in the current position, and working with his or her current supervisor. In the national culture section (section 2), questions are about life values and national culture dimensions. In section 3, this study use Hofstede's notion of organizational culture. Hofstede developed six dimensions of organizational culture: (I) PI Results oriented versus process oriented: A results oriented culture is one where organizational practices are perceived to reflect a concern with goals and goal achievement; a process oriented culture is one where practices are perceived to reflect a concern with means; (2) P2 Job oriented versus employee oriented: A concern for getting the job done versus a concern of people; (3) P3 Professional versus parochial: A professional culture is one in which "people identify with their type of job" compared to a parochial culture in which “employees derive their identity largely from the organization"; (4) P4 Closed system versus open system: this refers to the perceived communication climate within the organization, with a closed system culture being seen as "closed and secretive", and an open system characterized as "open to newcomers and outsiders"; (5)Tight versus loose control: this refers to the amount of internal structuring in the organization. Hofstede notes that it equates to the tight versus loose distinction in management control literature; (6) P6 Pragmatic versus normative: "pragmatic units are market-driven: normative units perceive their task towards the outside world (customers and clients) as the implementation of inviolable rules". Section 4 in the interview relates to supervisor's performance evaluation, which consists of four items (QI8-Q2I). This section is partially developed based on Hartmann and Slapničar's (2009) instrument on performance evaluation formality. The last section, section 5 , is about interpersonal trust or trust in the supervisor. This section adopts Read's (1962) instrument on interpersonal trust with some modifications, so it fits with the interview context.

It is important to acknowledge that the purpose of our qualitative analysis is not only to build a linkage between concepts or categories (a combination of concepts), which are based on literature, but also to discover new concepts. The outcome of this process is a model which shows the interplay of factors, by testing out 
the relationship between elements of the study and explaining complex processes behind it. This study adopts Flick's (2006) steps to analyze the qualitative data. NVivo 9 is used for qualitative data analysis.

\section{RESULT AND DISCUSSION}

Initially, this study analyzed the national culture profile of the interviewees and linked them to their life values. This allowed me to find that particular life values are related to a particular national culture dimension. The result depicts the relationship between life values and their links to corresponding national culture dimensions, which are discussed in the following sections.

Nineteen interviewees in this study were concerned with building a good relationship with other people. They argued that they cannot live without others as they needed somebody to help them to accomplish their mission in life, and they perceived themselves as part of the wider society. They believed that their attitudes should be aligned to those that society demands, and they would benefit from doing so. Manager $\mathrm{G}$ described this as follows:

The environment for my family is very, very important or may even more dominant because we cannot live alone. At home, we did something to the environment, by doing religious activity. We know each other, and we maintain our relationship, physical or spiritual, with our surroundings. In a result, the security of the environment is also improved.

Good relationships are important to a highly collectivist country such as Indonesia and this is evident at Delta Indonesia in every organizational level and position. The collectivism profile is strongly linked to life values including empathy, being a trusted person, showing honesty and sharing with others. These values are related to one of the core values in collectivism and that is social harmony. Collectivist people adjust their actions with certain norms so their society will remain harmonious. Values within this culture are more focused on how to understand other people and have a good relationship with others, so in the end they can live peacefully. It is found that the people who have empathy always try to understand other people and find the reasons behind their actions.

Interviewees who believed in honesty and being a trusted person think that lies and cheating will harm themselves and others, since they violate the norms of society. 
National and Organizational Culture...

Unggul Purwohedi

In terms of sharing with others their values, interviewees believe that by helping each other they can reach a common goal and better outcomes rather than acting as an individual. They need to socialize with others and have a mutual relationship so in turn they can achieve a harmonious and prosperous life.

This study found a significant gap concerning expatriate and local managers and employees' perception of power distance culture. Most of the expatriates expressed their feelings about high power distance profile in Indonesia, which reflects Indonesian people's perception of hierarchy, especially in terms of decision-making and discussion process. As indicated by Director B:

In Indonesia, people have a higher hierarchical look of each other, so people from different levels, may be too far apart from their supervisors. Here, it is not likely for someone to make complaint to the boss, in the US you can discuss, you can disagree, you can argue, but even in the US at the end, somebody has to make a decision, usually the boss. In Indonesia the problem is people don't give you their opinion, because they think, supervisors know everything.

This huge power distance has also been described by Director $D$, which sometime makes him feel frustrated:

Indonesia is a country where the distance between the hirarchical levels are huge, which means the boss is always right.You cannot discuss with him,every body is okay with the boss, agree with the boss.. For me its quite frustrating. Because, I like when people can say what they want to say, can give argument, can provide added value. in the global mindset, human being is a flawless, it must have home for this concern. When in the process of making decision, employee could dicuss, but in Indonesia is quite difficult to come this kind.

From Director D's statement, it can be seen that he prefers equality instead of hierarchy because it will enable personnel to discuss all matters since there will be no fear of punishment from higher level staff. This is rare in the Indonesian context but this study has revealed why hierarchy is highly regarded by Indonesian people. They generally believe in a leader who is able to make decisions for them because most Indonesian people feel that it is not easy to get the correct decision for many people. 
They rely on a leader who will take the responsibility to make a final decision, whether it is right or wrong. Manager $\mathrm{K}$ described this situation as follows:

So, sometimes we need people, who have a higher hierarchy to say that you have to work, don't ask, just do it. At certain level we should have them; On the one hand, we might be happy if we can talk together about our work. On the other hand, sometimes we cannot achieve an agreement, so we need a person who decides and says 'Okay l'Il take this opinion and we go with this decision'.

Apparently, this large power distance profile reflects the value of respect for older people in Indonesian culture. Senior members of society have several privileges such as being recognized as informal leaders for younger people. This is evident at Delta Indonesia, other private companies and government institutions in Indonesia. There is also a perception that a higher position is equal to a senior level in the organization. This finding is consistent with that of previous studies on Indonesia's power distance profile.

In order to explore the related values in this dimension, interviewees were asked their perceptions of the meaning of success and how they achieve it. We found that in terms of success, most people argued that it is not in money or career terms only. Success is also related to having family, friends, and understanding their wider environment. They recognized this life balance, not only in their career life but also for family and the wider environment, as described by Manager E:

For me now, success is, if I can balance life at work and in family. My company is pleased with my performance, subordinates are happy with their performance. I am enough. Next target, my success is my environment, and maybe I haven't done it yet. But it is a target for me, how to do more in church, as well as for my environment at home. That's it. My current balance is still limited to family and office. If it is balanced then [I can] do next.

One expatriate director, Director $\mathrm{C}$, also expressed the same principle that a successful person is one who can balance life and work. Moreover, Director D also underlined that success cannot be measured only in terms of money: 
National and Organizational Culture...

Unggul Purwohedi

I don't believe that power [is only] on money, we can link success with power on money, [it] is true, but I dont think it's the main criteria. Having more money is good, but when you reach it, you [want] more, [and it] don't make sense. Personally, I don't have big needs, so that's okay for me.

Moreover, our results suggest that being grateful is related to the femininity dimension. Grateful in this context means being happy for whatever has been granted by God to a person. This perception, in turn, builds a mindset for certain individuals not to be greedy for wealth, since money is not their ultimate goal. Employee $\mathrm{P}$ commented on this value:

Success for me is when we are successful in achieving what we want both the material and the religion. So, I try in my life to be grateful, the value of life, which is inspired by my parents. I believe it is true. So if there are people who say, you'll be successful person if you have a lot of wealth, I think it's not. Success means we are enjoying our life.

The femininity dimension is more dominant in Delta Indonesia compared to masculinity. However, some local managers showed their concern that success in their career meant achieving certain targets. Apparently, they dedicate their lives to achieving a higher position by working hard and being committed to the job more than anything else. They believe that competency and experience are the key success factors in how they achieved their current position.

The uncertainty avoidance dimension did not appear to be related to a life value. Previous studies have acknowledged that Indonesia is a middle range country in this dimension, but there is little evidence that uncertainty avoidance culture is related to a life value. Secondly, uncertainty avoidance is related to anxiety about the future so there is a higher emphasis on rules and procedures. It is found that rules and procedures become less effective in Indonesia due to the fact that Indonesian people tend to deviate from them. Sometimes, they tend to be more pragmatic in their concern for the present rather than worry about the future. Therefore the uncertainty avoidance culture seems to be irrelevant to the life values in this study.

This study explored how life values could be classified into several national culture dimensions like collectivism, large power distance, and femininity. Those are 
the prominent dimensions in Delta Indonesia. To develop a more comprehensive model, the next section will discuss the relationship between national culture and organizational culture at Delta Indonesia.

How national culture might have an impact on organizational culture orientation through some emerging themes is discussed here. Previous studies have shown that organizational culture is influenced by national culture (Chow et al., 2002; Hofstede, 1998; Hofstede and Peterson, 2000).

Teamwork is the main element, which influences the employee-oriented culture. One of the definitions of being employee oriented is that decision-making is done by teams and not individuals. Teamwork is the basis for doing everything in this company. It may be related to the project-based nature of the company where teamwork is required to achieve certain targets. Directors, managers, and employees as a team will communicate intensively when deciding the appropriate action to achieve a target.

Delta Global has endorsed this teamwork atmosphere intensively in that a people focus is one of its main core values. Teamwork has been widely implemented in Delta Indonesia at all staff levels. Sharing with others cultivates good communication and the value of helping each other has been acknowledged as contributing to teamwork and communication process. There are links between communication, sharing with others and team work. As mentioned earlier, this sharing with others value emerges from a collectivist national culture, which is reflected in building a harmonious relationship.

Teamwork is also influenced by the mindset of trust in other people. People who have a high level of general trust will presume that others can be trusted, others have a good intention and behavior, and others are competent enough to do the right things. These assumptions, then, will enable people to sit together as a team and where everyone can talk to their supervisor without fear or favour. The value of equality derives from a small power distance national culture. In Delta Indonesia, expatriates are frequently associated with trusting behaviour. Managers and employees who have worked together with expatriates feel that they are more trusted because they are able to communicate with their subordinates without too much anxiety about their capabilities. 
National and Organizational Culture...

Unggul Purwohedi

There is a strong relationship between collectivism, large power distance and employee oriented culture. Employees and managers have relatively similar perceptions regarding employees' orientation. Both levels experience working in teams in their routine assignments. Decisions are made by all team members, including supervisors and subordinates. Employees feel that their organization is concerned about their interests and opinions. Moreover, most employees think that they have a supportive environment where they can communicate with each other. They can share their problems with their colleagues and especially with their supervisor. This culture also has been cultivated as the result of the company's focus on people.

There is a connection between themes, which in turn relate to small power distance, collectivism and open-system oriented. Open-system oriented culture is closely linked to willingness and the quality of a relationship established by directors, managers, and employees. There are many ways to establish a good relationship, such as through a good and intensive communication, personal approach and being honest with each other. Employees need a more personal approach with their supervisor; they need to be understood, in order to feel that they are being taken care of. The feeling will enhance the quality of the relationship between supervisors and subordinates.

Another important theme is being honest with each other and this means being open to what might be relevant to the subordinates or to the job. This transparent value is associated with equality and honesty. Equality means a paradigm where everyone has the same rights to access information and being treated equally. Equality again is related to the small power distance, whilst honesty is related to a collectivist national culture dimension. Like general trust, transparent behavior is related to expatriate themes, where most expatriate directors feel that they have been transparent about everything that people need to know which in turn is fruitful for relationships. They have regular meetings that help everyone to communicate with each other about what might concern them, their work, or sharing current issues in their department or unit. Informal meetings are useful for supervisors to know more about their subordinates, to check subordinates' understanding of what has been discussed in the formal meeting, or just to establish a better relationship. It is 
therefore evident that collectivism, small power distance, and the open system orientation of an organizational culture are inter-connected.

It is emerged in this research that only one national culture dimension is related to the closed system orientation, and this is the large power distance culture. Closed-system orientation exists when information is not shared and there is nonnegotiable behavior when decisions are made. Not shared information can be caused by some issues such as the perception of hierarchy and the personality of the supervisor. According to hierarchy, in some occasions a group leader may not be honest enough with the project leader and communication channels are blocked or discouraged. Thus, there is a bottleneck in communication and coordination. There is a great distance between one level and another and equally important, the decisionmaker is not proactive enough and bypasses this process by directly meeting with the lowest level employees, for instance. People can feel comfortable with a hierarchical structure and this mindset is created by their inner values such as respect for higher authority.

Not shared information is a disservice to employees because sometimes their supervisors keep things confidential or secret what should be transparent such as promotion prospects or job rotation. Local managers on some occasions even decide which subordinate could be promoted and who does not without any honest criteria. Another example is when a department head announces an internal vacancy, but a newcomer gets the job instead. In this situation the employees know these managers as a 'safety player'. A safety player manager is one who will save his position by negating his or her subordinates' best interests.

There is the contrast between managers' and employees' perceptions of closed-system orientation. Managers do not see this company is being closed but employees think differently. Managers perhaps as the result of their daily interactions with expatriates bring an open culture to their leadership style. Some employees feel that their current supervisors are more secretive about their policies where they keep some information secret. Result indicates that eventhough localmanagers practice an open culture some could demonstrate a more closed culture to their subordinates. This could constitute important evidence about the effectiveness of organizational culture transfer via expatriate deployment to MNC subsidiaries. In this case, local 
National and Organizational Culture...

Unggul Purwohedi

managers are the key actorsinthe organizational culture transfer process. Local managers' inability to transform an expatriate's working style with local subordinates is the critical point in this process.

Competency is the critical factor in professional orientation. In a professional culture the company or supervisor is highly regarded if they have competency and therefore subordinates' respect. A supervisor's relationship with employees is based on work issues and achieving targets regardless of the background of the employee. Competency is associated with the job description of a person and specifically top SOP (Standard Operation Procedures) about what actions need to be done. However, in some circumstances, it is not always easy to follow the procedures especially where there is the risk of bribery. Employee $\mathrm{R}$ relies on her principle of honest behavior when the risk of bribery emerges, and she learnt this principle from her father. This organizational culture orientation is related to the honesty of what has been done, and honesty about company rules and procedures. Employees maintain the value of group cohesion and loyalty to the company (Keles and Aycan, 20II). A collectivist national culture has contributed to the professional orientation in Delta Indonesia.

As mentioned previously, competency is related to the quality or achievement of workplace duties and to the value of hard work. When someone devotes his or her life to some competency or skill, his or her hard work contributes to workplace efficiency. This hard work value is often associated with a masculine national culture. It appears that professional orientation is the result of individualistic national culture dimensions, in that professionally oriented people only focus on work matters and put less emphasis on personal issues. In summary, professional orientation is related to three national culture dimensions: collectivism, masculinity, and individualism.

In terms of performance evaluation, Delta Indonesia uses what is called the Delta System (pseudonym), which enables supervisors and subordinates to set and monitor workplace targets over the year. There is a review cycle for everyone in this company and this occurs three times a year. At the beginning of the year, supervisors meet their subordinates to set the objectives and this entails asking for subordinates' opinions. These are documented in the Delta System, which will guide the monitoring 
process of the subordinate's performance evaluation for the next six months. In the mid-year, supervisors and subordinates meet again in the cycle review, to evaluate what has been achieved. Here, subordinates can propose changing certain targets due to changed circumstances. Usually, they will aim for a new objective and by the end of the year at the third review; they will evaluate the overall performance based on the latest agreement between them.

According to the cycle review process, which includes a formal performance evaluation, supervisors and subordinates have a written agreement as a reference point for evaluating employees' performance. Several objectives need to be achieved over the course of a year. There is also a communication process in the form of discussions when establishing these targets. This process is aligned with rules and procedures and involves everyone at Delta Indonesia. Subordinates need to produce evidence of what they have achieved according to key performance indicators.

It is recognized that the decision will be made on a consensus basis, not just the supervisor's opinion. So there is an attempt to accommodate the employee's interests and concerns. We conclude that there are connections between open system orientation, employee orientation, and formal performance evaluation. Moreover, professional orientation is associated with the competency-based themes. Data and evidence can indicate the competency or ability of subordinates to do their jobs. A professionally oriented organization will judge that its employees are capable enough. It is evident that in an open system, employee orientation and professional orientation are related to formal performance evaluation.

In terms of an informal performance evaluation, the theme of subjectivity is central to this process. Result indicates that the subjectivity of a supervisor when evaluating his/her subordinates is related to three concepts: attitude and behavior, personal judgments, and other managers' comments. For attitude and behavior, local managers feel that it is insufficient to only rely on an objective measurement such as a quantitative goal. It is important to complement this achievement with good attitudes and behavior evaluation. Good results achieved with a bad attitude are worthless. Manager $\mathrm{E}$ commented on this: 
National and Organizational Culture...

Unggul Purwohedi

I think yes, once again, working it's not just what is on the paper. For me, the important thing is not only my sales person get 5 million dollars order per year. But, if he get this order by getting drunk with the clients or making somebody elses upset, I won't count this. I am concerned about how my sales person reach the target, how colleagues' opinion on him or her, how he or she cooperate with his friends, and so forth. There is subjective evalution there. Nevertheless, I still have to rely on existing data. It would be much better if the data is good, and his attitude is good as well. I want to have both.

Therefore, subjectivity is needed when evaluating subordinates' behavior. This concern with employees' attitudes and behavior is an indication of being employee oriented, where the supervisor is not only considering the results but also subordinates' personalities. Personal judgment appears to over-ride the objective data. For instance, objective evidence is that a subordinate's achievement is outstanding but they do not receive a bonus. The perception is that the supervisor lets his or her personal judgment gloss over the evidence. The supervisor is secretive aboutthe reasons why this is the case and such secretive behavior indicates a closedsystem orientation. As stated by Employee P:

Could company policy be different in two departements? Which is considered to be confidential in Departement $A$, and unconfidential in Departement $B$ ? It is strange like that, so my opinion, it could be very subjectivity, depends on the department head. It is considered to be confidential according to department head, but to the other department heads it might not be confidential.

This study found that that some supervisors also considered other managers' comments as the basis for evaluating their subordinates. Delta Indonesia's matrix structure means that in any one project, an employee could have several supervisors. Therefore, the direct supervisor needs to listen to other managers' comments about how well subordinates are working. The other managers will describe employee performance on the appraisal sheets.

There is a link between subjective informal performance evaluation and unstructured performance measurement. Director A observed that formally he still recognizes KPls when evaluating his subordinates. However, the final decision is based on understanding the reasons why his subordinates achieve a certain 
level. He will communicate this with them through a consensus process. As he described:

We do achieve our KPIs, based on facts then we [consider] subjective things. We have to try evaluate [subordinates] whether they generally did a good job or not. Considering all the things going on. Company change a lot.. a lot of reorganization in this company. [Thus], all the KPIs are a little bit messed up. I would say it's not so structured.

This system is more suitable for the sales team where targets can have a degree of flexibility, unlike the finance or engineering departments. This argument supported by Manager E:

For salespersons, not necessarily they report to me every day. You are the man, this is your account, five companies, I need your results. I just see how they work, what should be approved and what is not, then they can run and dealing with others as a team.

In contrast this study shows that managers' perceptions of supervisor's informal performance evaluation style is less than at the employee level. It indicates that local managers evaluate their subordinates more informally, eventhough they have been evaluated more formally by their expatriate directors. This finding is evidence for the lack of a local manager's role in transferring organizational culture. Local managers experience a more formal performance evaluation but they prefer more informal ways to evaluate their subordinate's performance. In the next section, we demonstrate that organizational culture orientation and performance evaluation formality have contributed to the trust-building process between supervisors and subordinates.

In terms of formal performance evaluation, result shows that there are two themes that are closely linked to interpersonal trust: one is fairness and the second is transparency. Formal performance evaluation is the explicit indicator for evaluating subordinates. For supervisors who rely on this evaluation, their subordinates will know they have been evaluated based on how well they work. This study finds that the open system has contributed to interpersonal trust building in Delta Indonesia. The open system brings fairness and transparency to employees that in turn cultivate a trustbuilding relationship between an open supervisor and his/her subordinates. Thus, a good trust relationship between supervisors and their subordinates creates a good 
National and Organizational Culture...

Unggul Purwohedi

atmosphere which subordinates can take a higher responsibility. As described by Employee X:

Actually the problem is not in technical matters, we have worked here for almost ten years, and so in terms of work, we have a good experience. The real problem is the convenience at the workplace; convenience is number one for us. Especially, having a good relationship with supervisor and colleagues.

Thus, from Employee X's comments it could be inferred that a trust relationship helps subordinates, which is very important for when they do their daily tasks. From the supervisor'sperspective, the trust relationship enhances the supervisor's willingness to provide larger responsibilities to other staff, as mentioned by Director D:

Trust is mutual, so if you lie to your subordinate he won't trust you, and if your subordinate lies to you, you won't trust him. So it is a mutual relationship. So to cultivate it, to make it stronger for me, is through mutual relationship of each other. It can bring efficiency to the organization, as well as more freedom to reach the target, more responsibility. Closed system oriented culture, informal performance evaluation, and interpersonal trust.

In terms of the relationship between informal performance evaluation and interpersonal trust, this study finds that supervisors can use their subjectivity to evaluate subordinates' performance, but only as long as this subjectivity has been communicated properly to subordinates. They will accept this and regard it as an input to enhance their performance in the future. For instance, if managers consider other comments from subordinates' colleagues and mentioned them in the performance evaluation process, then as long as these comments are constructive a subordinate will accept this. In contrast, if this informal performance evaluation is not transparent or too secretive then in many cases it leads to unfairness in the workplace. This frequently happens in three areas, employee promotion, employee rotation, salary and bonus, and can lead to a decline in interpersonal trust. A similar process is evident in the closed system orientation regarding interpersonal trust where unshared information lessens trust building. This study finds that employees need appreciation from the supervisor. In many cases employees do jobs outside their formal job 
description, and this should be appreciated in the performance evaluation. It has proved to be an effective way for having better relationships with employees, and building trust at the same time. Employee $X$ commented:

The important thing is teamwork; the leader is not a superman who knows everything. The main role of a leader is to coordinate his subordinates. So, I will succeed because my team supports me. The success of the project is depending on the team, so if this project already accomplished, [let us] give our appreciation to the team, such as well done...that's also a form of support.

It is clear from the findings that Indonesian Managers are uneasy to trust their local subordinates. This behavior can be understood as a reflection of low of interpersonal trust behavior among Indonesian people. According to recent surveys on interpersonal trust index across 100 countries, Indonesia is one of the countries that have the lowest score on interpersonal trust index. In other words, most of Indonesian believes that it is not easy to trust most of people in Indonesia. They need to be careful when they are dealing with people. Local managers are experiencing the open communication and trust behavior form their expatriate managers, but in the same time, they need to think twice to implement these on their local employees. Thus from our perspective, the local manager is very important layer to develop trust within MNC subsidiary. On the one hand, if they decided to become secretive and unfair then the outcome will diminish trust relationship. On the other hand, if they decided to be more transparent and fair in the evaluation process, then interpersonal trust will be fostered.

This paper started with Giddens' (199I) theory, which was extended to the study of a MNC subsidiary. According to these study findings, it is clear that organizational culture and its practices do have a significant impact on the performance evaluation system. On the one hand, the MNC implanted the parent culture (joboriented and open-system culture) to its subsidiary that in turn contributed to more formal performance evaluation. MNCs are able to shape their subsidiaries with an established formal performance evaluation system and this can happen as the consequence of a MNC's parent organizational culture. This study also showed that national culture has an impact on organizational culture preference. It emerged that 
National and Organizational Culture...

Unggul Purwohedi

power distance and collectivism together have an influence on P2 dimension (employee vs. job orientation). This is supported by the findings in other studies (Efferin and Hopper, 2007; Iriyadi and Gurd, 1998; Suutari, et.al, 200I), where most Indonesians value a harmonious relationship with others and respect group cohesiveness.

On the other hand, this study revealed that the preference for a performance evaluation formality also have been influenced by a parochially oriented culture. This comes from a large power distance and collectivist culture that local members share and it confirms that Indonesian staff perceived their workplace environment as being similar to their social environment. They perceived that their parochial culture is also applicable to their job-related one and consequently the performance evaluation formality emerged from this perception. This study also revealed that employee and closed-system orientation, which reflects Indonesian culture, has created a more informal preference for performance evaluation. Indonesian managers appeared to be the most important layer in this specific preference, yet they experienced more formal performance evaluation from their expatriate supervisors. These results provide strong evidence for the existence of Giddens' re-embedding process in Western MNC subsidiaries in Indonesia. The local context develops the established performance evaluation practices for local managers. In turn, this has an impact on local employees' trust in their supervisors.

\section{CONCLUSION}

This paper has investigated the role of national culture and organizational culture in performance evaluation and interpersonal trust in a multinational company's subsidiary in Indonesia. This paper strived to understand the source of culture for expatriate and local members, the interaction between national and organizational culture, the impact of organizational culture on the performance evaluation process, the influence of performance evaluation on trust-building between subordinates and their supervisors. Lastly, it looked at an organization's contribution to the concept of trust building. Consistent with other studies about Indonesia, this study found that power distance became one of the important national culture profiles in local staff members. However, this study discovered a small power distance culture profile lies in some expatriate directors who practiced flexibility and equality in the workplace, especially when dealing with the local managers. Unfortunately, those local managers 
did not totally practice this small power distance culture when they interacted with their local employees. Findings from qualitative analysis showed that collectivism and small power distance have contributed to the preference of a more employee(people) orientation and open-system orientation in this Indonesian subsidiary. Large power distance contributed to the closed-system organizational culture preference due to unshared information between local employees and their local managers. A professional orientation interacted with individualism, masculinity and collectivist national culture dimensions.

The analysis also found that open-system, employee, and professional orientation fostered a more formal performance preference in the Indonesian subsidiary. On the other hand, employee and closed-system orientation increased the preference for a more informal performance evaluation. The findings show that formal and informal performance evaluations are present in this study. Both of those evaluations did greatly benefit from organizational cultural practices, and highlighted the effectiveness of performance evaluation implementation. According to the relationship between performance evaluation formality and interpersonal trust, the analysis revealed that both formal and informal performance evaluation do increase the trust relationship between supervisor and subordinate. Formal performance evaluation enhances fairness in the evaluation process and this is good for the trust-building process. Informal performance evaluation is also effective for building trust as long as it is implemented in a more transparent way. In some cases, local employees are also feeling comfortable with this subjective performance evaluation as it brings a closer relationship with their supervisors.

We conclude this paper with several suggestions for follow on research. It is recommended that further research can be undertaken in the following areas. First, the future study can undertake the similar research not only in Western MNC, but also Eastern MNCs. It has been argued by many international business researchers that the current focus of international business attention has shifted to the emerging economies such as China, South Korea, India, and countries in South-East Asia. These developments may create insights about how Eastern MNCs cope with local cultures compared to Western MNCs. Second, future studies may conduct large-scale quantitative surveys including MNCs in many industries and many countries. A larger 
National and Organizational Culture...

Unggul Purwohedi

survey also enables us to see a comprehensive pattern of MNC practices in Indonesia and to understand how Indonesians interact with each MNC's different or similar cultures. Third, future studies may focus on the impact of organizational sub-cultures within a MNC subsidiary. It will be fruitful to analyse the organizational culture across unit level, SBU, and departments. Fourth and last, future studies could investigate other Management Accounting System methods such as Balanced Scorecard, Activity-Based Costing, Economic Value Added, as these methods have been used widely.

\section{ACKNOWLEDGE}

Author acknowledges the significant contribution from Professor Helen Thorne and Assoc. Professor Bruce Gurd for their constructive comments, theoretical foundation, and conceptual clarification during this paper writing.

\section{REFERENCES}

Bhimani, A. (1999). Mapping Methodological Frontiers in Cross-National Management Control Research. Accounting, Organizations and Society. 24(5-6): 4I 3-440.

Buckley, P. J., \& M.C. Casson. (2009). The Internalisation Theory of The Multinational Enterprise: A Review of the Progress of a Research Agenda After 30 years. Journal of International Business Studies. 40 (9): I563-I 580.

Busco, C., A. Riccaboni, and R.W. Scapens. (2006). Trust for Accounting and Accounting for Trust. Management Accounting Research. I7(I): I I-4I.

Busco, C., E. Giovannoni, \& R.W. Scapens. (2008). Managing the Tensions in Integrating Global Organizations: The Role of Performance Management Systems. Management Accounting Research. 19(2): 103-125.

Carmona, S., M. Ezzamel, \& F. Gutierreez. (2002). The Relationships Between Accounting and Spatial Practices in The Factory. Accounting, Organizations and Society. 27(3): 239-274.

Chow, C. W., M.D. Shields, \& A. Wu. (1999). The Importance of National Culture in The Design of and Preference for Management Controls for Multi-national Operations. Accounting, Organizations and Society. 24 (5-6): 44I-46I.

Chow, C. W., G.L. Harrison., J.L. McKinnon., \& A. Wu. (2002). The Organizational Culture of Public Accounting Firms: Evidence from Taiwanese Local and US Affiliated Firms. Accounting, Organizations and Society. 27(4-5): 347-360. 
Dossi, A. \& L. Patelli. (2008). The Decision-influencing Use of Performance Measurement Systems in Relationships Between Headquarters and Subsidiaries. Management Accounting Research. 19(2): 126-148.

Efferin, S., \& T. Hopper. (2007). Management Control, Culture and Ethnicity in a Chinese Indonesian Company. Accounting, Organizations and Society. 32(3): 223262.

Evans, L. (2004). Language, Translation and The Problem of International Accounting Communication. Accounting, Auditing, and Accountability Journal. 17(2): 210-248.

Flick, U. (2006). An Introduction to Qualitative Research. London: Sage Publications.

Giddens, A. (1991). The Consequences of Modernity. California: Stanford University Press.

Harrison, G. L., \& J.L. Mckinnon. (1998). Editorial: Culture and Management Accounting. Management Accounting Research. 9: I I3-I I8.

Hartmann, F., \& S. Slapnicar. (2009). How Formal Performance Evaluation Affects Trust Between Superior and Subordinate Managers. Accounting, Organizations and Society. 34(6-7): 722-737.

Hofstede, G. (1998). Attitudes, Values and Organizational Culture: Disentangling the Concepts. Organization Studies. 19(3): 477-493.

Hofstede, G., \& M.F. Peterson. (2000). National Values and Organizational Practices. In N. M. Ashkanasy, C. P. M. Wilderom \& M. F. Peterson (Eds.), Handbook of Organizational Culture and Climate. London: Sage Publications.

Hofstede, G. (200I). Culture's Consequences: Comparing Values, Behaviors, Institutions, and Organizations Across Nations. London: Sage Publications.

Iriyadi, \& B. Gurd. (1998). Cultural Effects of Budgetary Participation: Indonesian Evidence. Asian Review of Accounting. 6(2): 7I-100.

Jones, T. C., \& D. Dugdale. (200I). The Concept of Accounting Regime. Critical Perspectives on Accounting. I2(I): 35-63.

Keles, S., \& Z. Aycan. (20II). The Relationship of Managerial Values and Assumptions with Performance Management in Turkey: Understanding Within Culture Variability. The International Journal of Human Resource Management. 22(I5): 3080-3096. 
National and Organizational Culture...

Unggul Purwohedi

Leung, K., R.S. Bhagat., N.R. Buchan., M. Erez., \& C.B. Gibson. (2005). Culture and International Business: Recent Advances and Their Implications for Future Research. Journal of International Business Studies. 36(4): 357-378.

Levy, O., S. Beechler., S. Taylor., \& N.A. Boyacigiller. (2007). What We Talk About When We Talk About 'Global Mindset': Managerial Cognition in Multinational Corporations. Journal of International Business Studies. 38(2): 23I-258.

Moilannen, S. (2008). The role of Accounting and Intermediate Subsidiary in The Management Control System. Management Accounting Research. 19(3): 252-269.

O'Donnell, E., \& J. Prather-Kinsey. (2010). Nationality and Differences in Auditor Risk Assessment: A Research Note with Experimental Evidence. Accounting, Organizations and Society. 35: 558-564.

Siti-Nabiha, A. K., \& R.W. Scapens. (2005). Stability and Change: an Intitutionalist Study of Management Accounting Change. Accounting, Auditing, and Accountability Journal. I8(I): 44-73.

Suutari, V., K. Raharjo., \& T. Riikkila. (200I). The Challenge of Cross Cultural Leadership Interaction: Finnish expatriates in Indonesia. Career Development International. 7(7): 4I5-429.

Vosselman, E., \& J.V.D. Meer-Kooistra. (2009). Accounting for Control and Trust Building in Interfirm Transactional Relationships. Accounting, Organizations and Society. 34(2): 267-283. 